\title{
Taxonomy and Chromosome Numbers of African Representatives of the Oryza officinalis Complex
}

\author{
by Tuguo TATEOKA*
}

Received February 17, 1965

As stated by some recent authors ${ }^{1,2}$, several problems in the taxonomy of the Oryza officinalis complex warrant further intensive investigations. Species of this complex are easily separated from all other species of Oryza and make part of the section Oryza (=section Sativa). This species complex is widely distributed in tropical and subtropical regions, but no species are common to the New and the Old Worlds. Some discussions of the taxonomy of the Old World representatives, with special reference to African species, are presented below.

In Africa there are two species in the officinalis complex: O. punctata Kotschy ex Steud. and O. eichingeri A. Peter. Our knowledge of the morphological distinctions between these two species has been rather limited, and it has sometimes been noted that delimitation of these taxa is obscure. The present author therefore made special efforts to examine a number of populations of O. eichingeri and O. punctata when he visited East Africa in 1964, and studied them from a taxonomic viewpoint. These results have already been reported in a previous paper ${ }^{3)}$. It was found that $O$. punctata and $O$. eichingeri differ in a combination of several morphological characters though a few intermediates are found. In this investigation several living stocks were also used. They had originally been collected in Africa and used as material for cytogenetic studies by many previous authors. Unfortunately, the present author found that some of these living stocks had been incorrectly identified.

In the National Institute of Genetics, Misima, there are two stocks (W0015 and W0043) which have been used for genetic and cytogenetic investigations of $O$. eichingeri. Stock W0015, which was identified as $O$. eichingeri by a previous investigator, was supplied by the Central Rice Research Institute, Cuttack. Stock W0043 was furnished by the United States Department of Agriculture, Beltsville. It is not certain whether W0015 and W0043 were derived from the same parental stock. These stocks were in turn distributed from Misima to various Institutes in Taiwan and the Philippines. Many cytogenetic investigations have been made on these stocks, and it has been repeatedly described that $O$. eichingeri is a tetraploid species with $\mathrm{BBCC}$ genomes.

Unfortunately neither W0015 or W0043 can be referred to $O$. eichingeri but are more correctly identified with $O$. punctata in the light of the present author's recent work $^{3}$. Stocks W0015 and W0043 have the following morphological features: Base of culms spongy and thick; ligules $3-5 \mathrm{~mm}$ long, soft, whitish; panicle branches spreading; spikelets $5.0-5.5 \mathrm{~mm}$ long, $2.1-2.3 \mathrm{~mm}$ broad; sterile lemmas triangular and acute; awns of the lemma almost straight; bristles on the awn rather rigid.

In all of these morphological features, W0015 and W0043 agree completely with the type specimen of $O$. punctata and differ quite significantly from true $O$. eichinger (see Tateoka $\left.{ }^{3}\right)$. As a consequence, the results of the many investigations made by previous cytogeneticists on material identified as $O$. eichingeri should not be applied

* National Science Museum, Ueno Park, Tokyo. 
to $O$. eichingeri but to $O$. punctata. Misidentification of the material is partly responsible for bringing about this confusion, but the fact that the taxonomy of Oryza has been in such unsatisfactory condition for so long has also contributed to these errors.

Other than stocks W0015 and W0043, the present author is not aware of any other strains named as $O$. eichingeri which have been used for cytogenetic investigations. True $O$. eichingeri does not seem to have been examined cytologically so far. The present author therefore studied chromosome numbers of the collections of $O$. eichingeri, as well as those of $O$. punctata, which were obtained in his recent explorations in East Africa. The results are summarized in Table 1.

Table 1. Chromosome numbers of Oryza eichingeri and O. punctata.

\begin{tabular}{|c|c|c|}
\hline $\begin{array}{l}\text { Strain number } \\
\text { in } \mathrm{NIG}^{1)}\end{array}$ & $2 n$ & Origin \\
\hline \multicolumn{3}{|l|}{ O. eichingeri } \\
\hline W1516 & 24 & Mabira forest, Mengo, Uganda ${ }^{2)}$. \\
\hline W1517 & 24 & Mabira forest, Mengo, Uganda ${ }^{2)}$. \\
\hline W1519 & 24 & Budongo forest, Bunyoro, Uganda ${ }^{21}$. \\
\hline W1520 & 24 & Ntandi forest, Bwamba, Uganda ${ }^{2)}$. \\
\hline W1521 & 24 & Ntandi forest, Bwamba, Uganda ${ }^{2)}$. \\
\hline W1522 & 24 & Ntandi forest, Bwamba, Uganda ${ }^{2)}$. \\
\hline W1524 & 24 & Ntandi forest, Bwamba, Uganda ${ }^{2)}$. \\
\hline \multicolumn{3}{|l|}{ O. punctata } \\
\hline W0015 & $48^{3)}$ & (supplied by the Central Rice Research Institute, Cuttack, India). \\
\hline W0043 & $48^{3)}$ & (supplied by the United States Department of Agriculture, Beltsville): \\
\hline W1024 & $48^{3)}$ & Kabokabo, Ghana (collected by Dr. K. Furusato). \\
\hline W1145 & $48^{3)}$ & (supplied by the Central Rice Research Institute, Cuttack, India). \\
\hline W1408 & 48 & Lagos, Nigeria (collected by Drs. H. I. Oka and W. T. Chang). \\
\hline W1512 & 24 & 15 miles north of Mariakani Coast Province, Kenya ${ }^{2)}$. \\
\hline W1514 & 24 & 5 miles north of Kwale, Coast Province, Kenya ${ }^{2)}$. \\
\hline \multicolumn{3}{|l|}{ Intermediates ${ }^{4)}$} \\
\hline W1525 & 24 & 1 mile southwest of Ntandi forest, Bwamba, Uganda2). \\
\hline W1527 & 24 & 3 miles southwest of Ntandi forest, Bwamba, Uganda ${ }^{2)}$. \\
\hline
\end{tabular}

1) National Institute of Genetics, Misima.

2) These strains were collected by the present author in 1964.

3) These counts were made by Dr. T. C. Katayama, National Institute of Genetics.

4) For details of the taxonomy and morphology of these intermediates, see Tateoka ${ }^{3)}$.

It is clear from Table 1 that $O$. eichingeri is a diploid and that both diploid and tetraploid forms occur in O. punctata. The diploid species O. eichingeri differ significantly in morphology from the diploids and the tetraploids of O. punctata, but the present author was not able to find clear-cut morphological differences between the diploids and the tetraploids of $O$. punctata $\left(\right.$ see Tateoka $\left.{ }^{3}\right)$. It is quite unfortunate that only a few living strains of $O$. punctata are now available for study. The taxonomic relationships between the diploids and tetraploids of $O$. punctata should apparently be further studied. It is also not known at all whether the diploids and the tetraploids have different geographical distributions. O. punctata is known to occur widely in Africa, from the Ivory Coast to Kenya and southwards to Southern 
Rhodesia and Madagascar. O. eichingeri is more limited in geographical distribution, known only from Kenya, Uganda, Tanganyika and the northeastern parts of the Congo.

As stated in various articles (e.g., Sampath $\left.{ }^{4}\right)$, both $O$. eichingeri and $O$. punctata have close relatives in Asia. O. minuta J.S. Presl ex C. B. Presl and O. officinalis

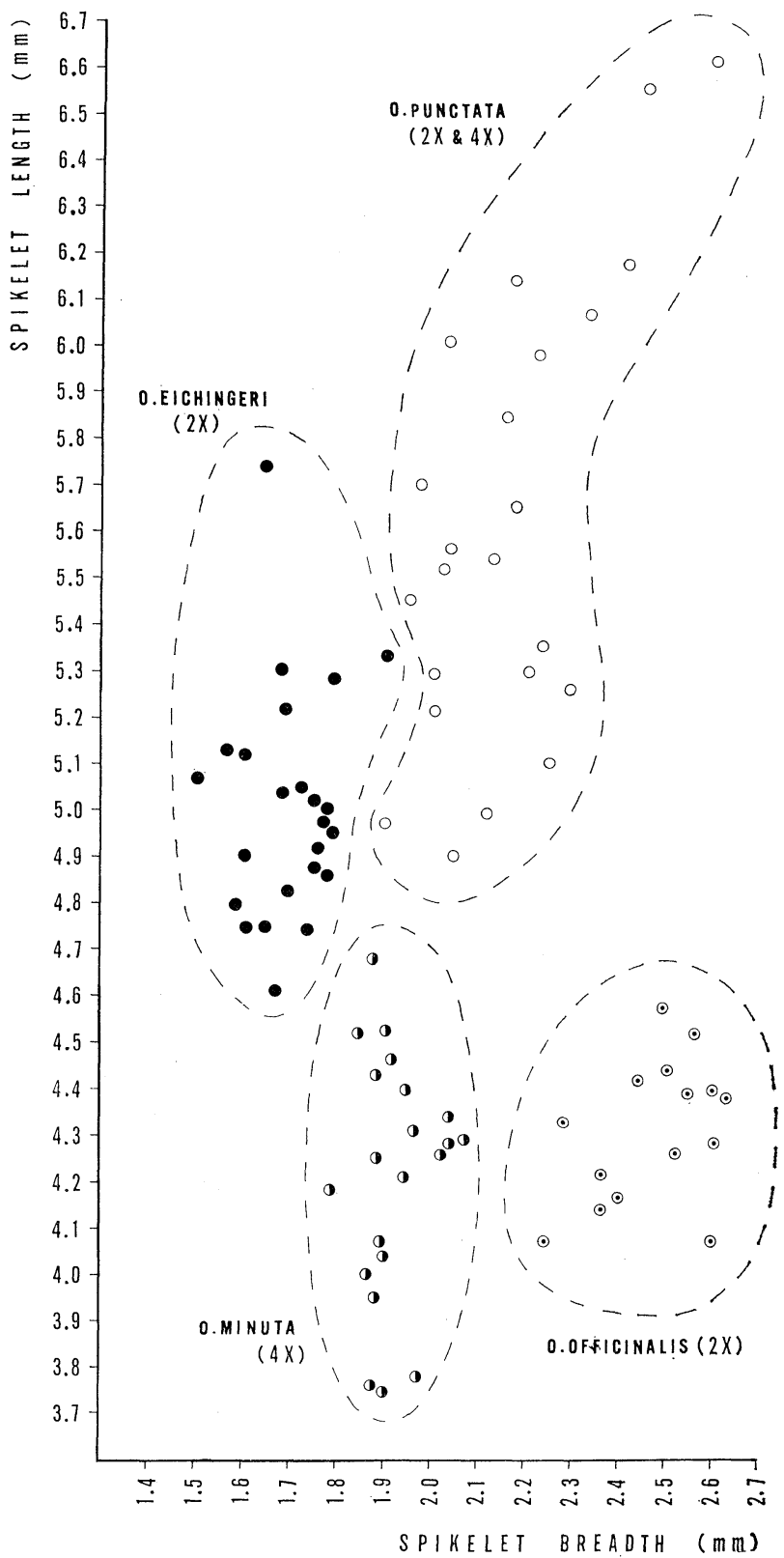

Fig. 1. Spikelet length and breadth of the four species of Oryza. One circle represents one collection. Measurements on O. minuta and $O$. officinalis were cited from Tateoka and Pancho5), and those on $O$. punctata and $O$. eichingeri from Tateoka ${ }^{3)}$. 
Wall. ex Watt are the two well known species of this complex in Asia (see Tateoka and $\left.\mathrm{Pancho}^{5}\right)$. O. officinalis is a diploid species with $\mathrm{CC}$ genome and O. minuta is a tetraploid with BBCC genomes (see Chang $\left.^{6}\right)$ ). In Fig. 1, which was prepared on the basis of results reported in previous papers by the present author (Tateoka and Pancho $^{5)}$; Tateoka ${ }^{3)}$ ), spikelet length and breadth of the four species (O. punctata, O. eichingeri, O. minuta, O. officinalis) are diagrammatically shown. This figure indicates that the four species differ from each other in spikelet characters. Tateoka ${ }^{7}$ has also described some other morphological differences between them based on herbarium studies. Nevertheless, there is no doubt that these African and Asiatic species are very closely related, since they share so many common features in morphology and are also cytogenetically inter-related.

There are two other taxa in Asia which may or may not be morphologically separated from the African species. One of them is a form found in Ceylon, which is very similar to $O$. eichingeri in morphological features and is likewise a diploid plant (this count was reported by Sampath $\left.{ }^{2}\right)$. Another Asiatic taxon, which also needs further study in relation to the African species, is a tetraploid form in Coimbatore, India. This taxon is generally called O. malampuzhaensis Krishnasw. et Chandrasek. It clearly differs from $O$. eichingeri but is similar to O. punctata. Further taxonomic investigations of these little known taxa should increase our understanding of the differentiation of the officinalis complex in the Old World.

\section{Summary}

It was shown that the strains, identified as Oryza eichingeri and used for cytogenetic investigations in various countries, are actually not true $O$. eichingeri but must be identified as $O$. punctata. Chromosome numbers of $O$. eichingeri and O. punctata were determined from 16 strains, the majority of which were collected in East Africa in 1964. All collections of O. eichingeri showed $2 n=24$. In O. punctata both $2 n=24$ and $2 n=48$ were counted. The relationships between these African species and some Asiatic species were discussed, and several taxonomic problems in this complex were pointed out.

\section{References}

1) Chang, T. T., Rice Genetics and Cytogenetics, 24 (Elsevier, Amsterdam, 1964). 2) Sampath, S., Rice Genetics and Cytogenetics, 22 (Elsevier, Amsterdam, 1964). 3) Tateoka, T., Bot. Mag. Tokyo 78: 156 (1965). 4) Sampath, S., Oryza 1: 1 (1963). 5) Tateoka, T., and Pancho, J. V., Bot. Mag. Tokyo 76: 366 (1963). 6) Chang, T. T., International Rice Research Institute, Tech. Bull. 1 (1964). 7) Tateoka, T., Bot. Mag. Tokyo 75: 418 (1962).

\section{摘 要}

館岡巠緒：Oryza officinalis complex のアフリカ産の種類の分類学と染色体数

国立遺伝学研究所で Oryza eichingeri として栽培されている2系統は, インドおよびアメリカ合衆国 の研究機関からゆずられたものであるが，これら2系統は O. eichingeri ではなく，O. punctataである ことが明らかにされた。これら2系統についてすでに沢山の細胞遺伝学的研究が抢こなわれ, O. eichingeri は4倍体 $(2 n=48)$ でBBCCぼノムをもつものであると，多くの論説にのべられているが，そのような研究結 果は O. punctata にきせられるもので，O. eichingeri にきせられるものではない，筆者は東アフリカ

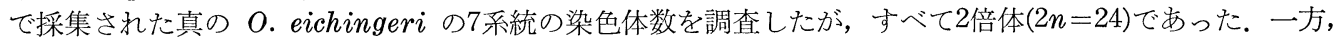
同様にアフリカ産の種類である O. punctata のなかには2倍体と倍体がある.旧大陸産の O. officinalis complex の分類学に抢いて，今後の研究をとくに要するものとして，1）O. punctata の2倍体と4倍体の 関係，2）O. eichingeri とセイロンにみられる2倍体の型との関係，3）O. malampuzhaensis の種として の独自性の3点があげられる。(国立科学博物館第一研究部) 